\title{
Feasibilities and effectiveness of web-based psycho- educational: a pilot study at universities students
}

\author{
Kadek Suranata \\ Universitas Pendidikan Ganesha
}

\begin{tabular}{|c|c|}
\hline Article Info & ABSTRACT \\
\hline $\begin{array}{l}\text { Article history: } \\
\text { Received Apr } 28^{\text {th }}, 2019 \\
\text { Revised May } 11^{\text {th }}, 2019 \\
\text { Accepted Jun } 10^{\text {th }}, 2019\end{array}$ & $\begin{array}{l}\text { This pilot study aims to determine the feasibilites and effectiveness of web- } \\
\text { based resilience programs at universities students. This study conducted by the } \\
\text { one group pretest posttest experimental design. The study participants were } 15 \\
\text { universities students at Universitas Pendidikan Ganesha Singaraja, Bali. The } \\
14 \text { items of Indonesian version resilience scale and the Health- Promoting } \\
\text { Lifestyle Profile (HPLP II) administrated to evaluated the eefect of program. }\end{array}$ \\
\hline $\begin{array}{l}\text { Keyword: } \\
\text { E-counseling } \\
\text { Resilience } \\
\text { CBT } \\
\text { Student well-being } \\
\text { School counseling } \\
\text { Students life style } \\
\text { Psychological health }\end{array}$ & $\begin{array}{l}\text { The open questioner of acceptablity and feasibies used to evaluated the } \\
\text { feasibility of the program based on students perception, and veryvication by } \\
\text { interview. The paired sample t-tes by JASP Versi } 0.10 .0 \text { performed to analisys } \\
\text { the data. The feasibilites program based on student perception is narated. The } \\
\text { results of this study indicate that: (1) the programs are effective to improve } \\
\text { student healt and life style and resilience, and ( } 2 \text { ) the program achieves high } \\
\text { acceptance and feasibility students. The results of the study have implications } \\
\text { for the e-counseling methods used in university. }\end{array}$ \\
\hline
\end{tabular}

Psychological health BY license (https://creativecommons.org/licenses/by/4.0/)

\section{Corresponding Author:}

Kadek Suranata,

Email:kadek.suranata@undiksha.ac.id

\section{Pendahuluan}

Stres dan depresi adalah salah satu bentuk risiko tertinggi yang mengancam kegagalan mahasiswa dalam mewujudkan prestasi akademik, keberhasilan karier dan khidupannya (Bandura, 1993; Dray et al., 2014; Martínez-Martí \& Ruch, 2017; Schulz et al., 2014). Untuk berhasil menghadapi resiko tersebut dengan baik, mahasiswa diperguruan tinggi memerlukan kemampuan untuk beradaptasi terhadap berbagai situasi yang menimbulkan strees atau depresi, serta digunakan untuk bangkit dari kegagalan. Suatu keterampilan dalam mengembangkan kognitif dan emosional yang positif serta perilaku adaptif.

Perilaku hidup sehat dan resiliensi merupakan dua hal terpenting yang menentukan kesehatan mental setiap individu (Lee \& Loke, 2007; VicHealth, 2015; Winston \& Chicot, 2016), termasuk para remaja, pelajar dan mahasiswa. Perilaku hidup sehat diperguruan tinggi dapat meliputi keterampilan untuk memelihara gaya hidup sehat, tanggung jawab terhadap kesehatan, memperhatikan aktifitas fisik, nutrisi yang cukup, interaksi sosial yang sehat dan mekanisme penanganan stress (Lee \& Loke, 2007; Walker, Sechrist, \& Pender, 1995; J. V Walker \& Lampropoulos, 2014). Perilaku hidup sehat ini dapat terwujud apabila individu memiliki keterampilan sosio-emosional yang baik untuk mengendalikan diri, mengelola diri, serta memotivasi diri untuk mewujudkan kesehatan pada dirinya

Untuk dapat mewujdukan perilaku dan gaya hidup sehat (health promote behavior), diperlukan juga daya tahan yang membuat individu mampu untuk tetap mewujdukan hidup sehat ditengah kesulitan, tantangan dan tekanan psikologis (Suranata, Atmoko, \& Hidayah, 2017a). Resiliensi atau ketahanan adalah kapasitas individu untuk merespons kesulitan atau trauma dengan cara yang sehat dan produktif untuk mendapatkan hasil yang produktif. (Luthar, Cicchetti, \& Becker, 2000; K. Suranata, Atmoko, Hidayah, Rangka, \& Ifdil, 2017). Resiliensi juga disebut sebagai seperangkat kekuatan pikiran dan emosi yang memungkinkan individu untuk mencari pengalaman baru dan memandang kehidupan sebagai kemajuan 
(Richardson, 2002; Winders, 2014). Lewinsohn, Hops, Roberts, Seeley, dan Andrews (1993) setidaknya 20\% siswa di seluruh dunia mengalami depresi, dan diperkirakan bahwa jumlah ini sekarang telah meningkat sepuluh kali lebih banyak. Pada siswa di Indonesia, gejala-gejala tersebut dapat dengan mudah diperoleh melalui informasi di media massa, media elektronik, dan media sosial terkait gangguan perilaku dan sosioemosional siswa atau remaja di Indonesia.

Sebuah studi yang dilakukan oleh Lee, dkk (Lee \& Loke, 2007) merekomendasikan bahwa universitas perlu untuk lebih peduli terhadap kebutuhan para mahasiswa untuk mengembangkan perilaku memelihara kesehatan dan kesejahteraan psikologis ditengah lingkungan social dan budaya yang berubah cepat di era milenial ini. Dalam komunitas universitas, upaya ini dapat berfokus pada upaya mengembangkan keterampilan untuk mempromosikan kesehatan, pengurangan risiko, dan pencegahan penyakit, meningkatkan ketahanan (resiliensi) untuk mewujudkan kesuksesan akademik, kesehatan mental dan kesejahteraan psikologis. Program pembelajaran atau pendidikan psikologis atau psiko-edukasi di perguruan tinggi adalah cara yang efektif untuk membantu mahasiswa mengembangkan keterampilan yang diperlukan untuk menghindari stres atau depresi. Program ini juga telah digunakan untuk mengatasi masalah kecanduan tembakau, alkohol, dan ganja di kalangan siswa (Frydenberg et al., 2004; Hodder et al., 2011). Dukungan empiris juga ditunjukkan dari hasil penelitian tentang program pelatihan psiko-edukasi seperti yang dirangkum dalam studi meta-analisis menunjukkan bahwa program pelatihan resiliensi mendapat penerimaan dan aksesibilitas sebagai bagian dari kurikulum di sekolah atau universitas untuk mengembangkan kesehatan dan kesejahteraan psikologis (VicHealth, 2015).

Mahasiswa dan pelajar di Indonesia saat ini akrab dengan penggunaan teknologi informasi dan komunikasi. Bahkan mereka akrab dengan media sosial seperti e-mail, facebook, twitter, blog, Skype, WhatsApp dan sebagainya (Chib, 2010). Studi tentang perilaku anak-anak dan remaja yang menggunakan internet oleh Kementerian Komunikasi dan Informasi Republik Indonesia menunjukkan bahwa sekitar 80\% siswa (anak-anak dan remaja, pelajar dan mahasiswa) di Indonesia adalah pengguna internet. Studi ini juga menjelaskan bahwa hanya $13 \%$ yang tidak secara intens setiap hari menggunakan internet (Broto, 2014). Pesatnya kemajuan teknologi informasi dan komunikasi pada era revoluasi industry 4.0 yang terjadi saat ini berdampak pada digunakannya media teknologi informasi dan komunikasi telah digunakan pada setiap dimensi kehidupan, termasuk dalam pendidikan dan juga konseling.

Ada kecenderungan bahwa program psiko-edukasi dan konseling tatap muka kurang diminati oleh siswa (Aaron B. Rochlen \& Zack, 2004; Andersson, Cuijpers, Carlbring, Riper, \& Hedman, 2014; Manicavasagar et al., 2014; Swank \& Tyson, 2012). Di Indonesia, penelitian oleh Hidayah (2015) mencatat bahwa konseling tatap muka hanya menarik bagi $15 \%$ siswa. Sedangkan sisanya, siswa memilih layanan konseling tidak tatap muka, seperti melalui media teknologi komunikasi seperti telepon, email, atau situs web. Sementara itu, kebutuhan siswa untuk layanan bimbingan dan konseling lebih tinggi, karena masalah, kesulitan dan hambatan yang dihadapi oleh siswa dalam pengembangan dan tugas akademik mereka semakin kompleks. Oleh karena itu, agar layanan konseling dilaksanakan secara efektif dan menjadi pemimpin dalam sistem layanan sekolah, online yang tidak terikat oleh jarak dan waktu diperlukan ketika berkonsultasi dengan konselor, bahkan di luar jam sekolah. Penggunaan metode online dalam konseling, termasuk dalam program pelatihan resiliensi adalah hal baru di Indonesia (Hidayah, 2015). Metode psiko-edukasi konseling berbasis web ini memiliki keunggulan dalam hal efisiensi waktu, dan dapat dilakukan tanpa batasan ruang dan waktu (Hedman et al., 2011; Hedman et al., 2014).

Terbatasnya bukti emperik yang membuktikan apakah metode psikodukasi konseling pada kalangan pelajar dan mahasiswa efektif dan memiliki penerimaan yang baik, khususnya di kalangan mahasiswa di Indonesia menjadi salah satu alasan metode ini belum menjadi salah kebijakan di perguruan tinggi. Sehingga penting untuk dilakukan pengujian apakah metode psiko-edukasi berbasis web pada mahasiswa di universitas efektif dan mendapat penerimaan dan manfaat bagi mahasiswa. Penelitian ini bertujuan untuk mengetahui keefektifan dan kebermanfaatan program psiko-edukasi berbasis web pada mahasiswa. Keefektifan program psiko-edukasi berbasis web di universitas ini dilihat berdasarkan dua variabel, yaitu perilaku hidup sehat yang diukur melalui scala gaya hidup dan kesehatan dan dan variable resiliensi yang diukur melalui skala resiliensi. Kebermanfaatan program dievaluasi untuk mengetahui pendapat para peserta terhadap kekurangan dan kelebihan program yang telah dilaksanakan serta sebera besar para peserta telah merasakan mendapatkan manfaat dari program psiko-edukasi berbasis website ini. 


\section{Metode}

\section{Rancangan penelitian}

Pilot studi ini dilakukan melalui metode eksperimental dengan desain one group pre-test and post-test. Penelitian ini melibatkan satu kelompok mahasiswa yang ditugaskan mengikuti program psiko-edukasi berbasis website (online). Terhadap kelompok partisipan ini, Di awal sebelum program dilaksanakan dan setelah program selesai dilaksanakan, terhadap responden dilakukan pengukuran terhadap variable perilaku hidup sehat dan resiliensi. Setelah mengikuti program, para responden juga memberikan pendapat mereka mengenai kebermanfaatan program melalui skala kebermanfaatan program psiko-edukasi berbasis web.

\section{Subjek penelitian}

Pilot studi ini melibatkan partisipan 15 orang mahasiswa S1 pada tingkat akhir (semester 7) dengan usia ratarata 19,4 tahun, 9 orang perempuan dan 6 orang laki-laki. Mereka dipilih berdasarkan hasil pengukuran tingkat gaya hidup kesehatan dan resiliensi yang berada pada kategori rendah dan/atau sedang, dari 65 partisipan yang telah mengikuti pengukuran awal. Para partisipan mengikuti program psiko-edukasi berbasis website (online) melalui sistem yang telah disediakan (http://www.cbtundiksha.com) dengan rentang waktu yang disediakan adalah 10 minggu (dua setengah bulan), yaitu dari minggu pertama bulan Juni sampai dengan minggu kedua bulan Agustus tahun 2019. Para partisipan dapat bebas memilih kapan waktu untuk mereka melakukan kegiatan melalui akses ke sistem, berdasarkan rentangan waktu yang telah disediakan. Para partisipan mendapatkan dana untuk pembelian paket internet selama mengikuti program. Para partisipan telah memahami bahwa hasil dari mengikuti program psiko-edukasi berbasis web ini tidak mempengaruhi nilai mereka pada mata kuliah dan program perkuliahan mereka.

\section{Instrumen penelitian}

Data yang diolah menunjukkan skala resiliensi versi bahasa Indonesia. Skala resiliensi ini mengukur lima dimensi aspek psikologis resiliensi, meliputi: keterampilan sosial; efikasi diri, kemempuan memecahkan masalah, kesadaran diri dan aspirasi tujuan. Skala ini terdiri dari 14 item yang dikembangkan dengan model skala Likert, dengan empat pilihan tanggapan, yaitu: sangat setuju (skor 4); setuju (3); kurang setuju (2) dan tidak setuju (1). Partisipan menjawab dengan memilih salah satu dari empat alternative pilihan tersebut. Skala resiliensi ini memiliki nilai validitas dan reliabelitas item dan faktor yang layak seperti telah dilaporkan pada studi Suranata, dkk (Suranata, Atmoko, \& Hidayah, 2017b)

Data gaya hidup dan kesehatan diperoleh melalui skala gaya hidup dan kesehatan, yang diadaftasi dari Health- Promoting Lifestyle Profile (HPLP II) Adult Version (Walker et al., 1995) yang telah melalui proses penerjemahan ke dalam Bahasa Indonesia melalui pakar Penerjamahan Bahasa Inggris-Indonesia. Skala ini mengukur lima dimensi gaya hidup dan kesehatan, yang meliputi: tanggung jawab terhadap kesehatan; aktifitas fisik; nutrisi, perngembangan spiritual; hubungan interpersonal; dan pengelolaan stress. Skala ini terdiri dari 52 item, yang pada setiap item responden memilih satu dari empat pilihan tanggapan, yaitu: selalu (skor 4); sering (3); kadang-kadang (2) dan tidak pernah (1). Skala ini memiliki tingkat Reliabelitas yang tinggi dengan nilai alpha Cronbach 0,95. Laporan hasil pengujian reliabelitas skala ini dapat di lihat pada https://osf.io/v2en3/ (Suranata, 2019a).

Data tentang feasibilitas program diperoleh melalui pengisian angket tentang penerimaan dan kebermaknaan program oleh partsisipan di akhir program. Wawancara terhadap perwakilan partisipan dilakukan untuk mengkonfirmasi hasil pengisian angket. Angket dan wawancara terfokus untuk menanyakan tentang: (1) prosedur dan tahapan setiap modul pada program; (2) teknik-teknik yang dijelaskan dalam modul; (3) banyak frekuensi dan rata-rata waktu yang digunakan (menit) partisipan mengakses sistem selama program berlangsung; (4) tampilan sistem; (5) manfaat program.

\section{Prosedur psiko-edukasi berbasis web}

Psiko-edukasi berbasis web ini merupakan program self-help online yang menggunakan kerangka model konseling kognitif perilaku (cognitive behavioral therapy). Prosesnya dapat digambarkan sebagai biblioterapi online, kontak antara mahasiswa dan konselor dilakukan secara daring. Setiap mahasiswa yang berpartisipasi dalam penelitian ini memperoleh akun pribadi untuk mengakses sistem psiko-edukasi berbasis web ini. Terdapat enam bagian modul utama yang telah dikembangkan dalam sistem ini, yang meliputi; (1) modul assessmen, yang berisi program self-assessment online gaya hidup kesehatan dan resiliensi; (2) modul psiko-edukasi 1, yaitu teknik restrukturisasi kognitif; (3) modul psiko-edukasi 2, yaitu teknik self monitoring; (4) modul psiko-edukasi 3, teknik problem solving dan decision making; (5) modul psiko-edukasi 4, teknik rileksasi dezensitiasi sistematis, dan (6) modul psiko-edukasi 5, teknik latihan asertif. Prosedurnya dapat digambarkan pada gambar 1 bagan alur proses psiko-edukasi berbasis web berikut. 
Berdasarkan gambar 1 di atas, prosedur pelaksanaan program psiko-edukasi berbasis web ini ini dijelaskan dalam 8 langkah berikut; (1) mahasiswa memasuki sistem program pelatihan ketahanan berbasis web dengan akun privasi, (2) mahasiswa mengikuti modul pengukuran awal untuk melihat profil gaya hidup kesehatan dan resiliensi mereka masing-masing, (3) mahasiswa mengetahui profil gaya hidup kesehatan dan resiliensi mereka dari hasil pengukuran awal, dan mendapat rekomendasi tentang modul-modul program yang perlu diikuti dalam program psiko-edukasi berbasis web, (4) mahasiswa mengikuti instruksi untuk setiap prosedur teknik yang disajikan dalam setiap modul, (5) mahasiswa melakukan evaluasi mandiri terhadap penerapan teknik yang telah dilakukannya dengan mengisi formulir yang disediakan di setiap bagian dari modul, mereka juga dapat mengirimkan hasil pelatihan mereka pada setiap sesi dan pesan kemajuan kepada konselor, (6) mahasiswa menunggu jawaban dari konselor, (7) berdasarkan evaluasi dan rekomendasi konselor, mahasiswa dapat melanjutkan ke modul berikutnya atau mereka dapat mengulangi dalam modul awal jika dianggap belum berhasil, (8) melakukan penilaian akhir (kembali ke modul assessment) atas rekomendasi konselor, jika telah dianggap tuntas untuk semua bagian modul psiko-edukasi.

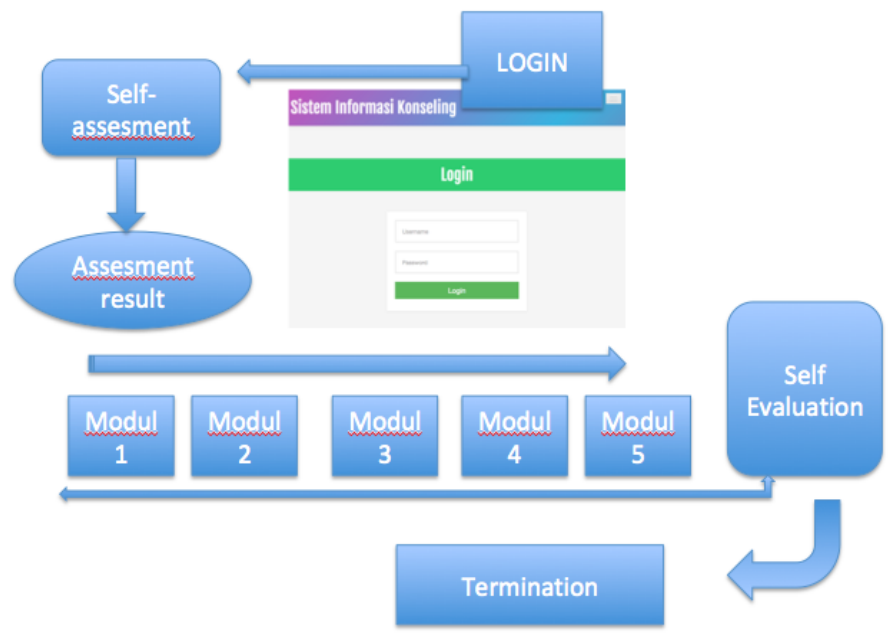

\section{Gambar 1. Prosedur Psiko-edukasi Berbasis Website}

Konselor dalam pelatihan resiliensi berbasis web ini memiliki peran untuk memantau, mengevaluasi keberhasilan mahasiswa yang mengikuti program psiko-edukasi berbasis website, serta merespon pesan yang disampaikan oleh mahasiswa. Prosedur yang dilakukan oleh konselor adalah; (1) menyediakan akun pribadi untuk mahasiswa dan mengundang mereka untuk mengakses sistem program psiko-edukasi berbasis web, (2) memantau kemajuan setiap kegiatan mahasiswa dalam sistem, (3) mengevaluasi keberhasilan mahasiswa, (4) memberikan rekomendasi tentang kelanjutan pelatihan dan hadiah untuk setiap mahasiswa, dan (5) jika perlu, konselor dapat mengirim pesan ke akun atau email mahasiswa atau melakukan contact melalui program video call (menggunakan program zoom), bisa juga pertemuan tatap muka jika mahasiswa menginginkan.

\section{Analisis data}

Analisis data dilakukan dengan menggunakan uji-t skelompok sampel berpasangan (paired sample t-test) yang dilakukan menggunakan program statistik JASP Versi 0.10.0 (Goss-Sampson, 2019). Keefektifan program psiko-edukasi berbasis web diuji berdasarkan perbedaan nilai rata-rata dua variabel yang diteliti, yaitu gaya hidup kesehatan dan resiliensi antara sebelum mengikuti program dengan setelah mengikuti program. Untuk mengoreksi besarnya pengaruh, juga dilakukan pengujian effect size menggunakan nilai d Cohen (GossSampson, 2019). Dataset JASP hasil analisis pengujian keefektifan program psiko-edukasi berbasis web ini dapat dilihat pada https://osf.io/tvpmj/ (Suranata, 2019b). Data tentang penerimaan dan kebermanfaatan program dari pengisian angket oleh partisipan dianalisis secara dekriptif kuantitatif juga dilaporkan persentasenya. 


\section{Hasil dan Pembahasan}

\section{Feasebilitas Psiko-edukasi berbasis Web}

Dari 65 responden mahasiswa yang diundang, hanya 15 yang dipilih menjadi partisipan dalam penelitian ini. Semua partisipan (100\%) mengikuti program psiko-edukasi berbasis web ini secara tuntas. Berdasarkan hasil tes awal, sistem merekomendasikan 7 orang siswa mengikuti seluruh modul (5 modul), dan 8 partisipan lainnya direkomendasikan mengikuti 4 modul. Rata-rata waktu penyelesaian adalah 9,5 minggu, lebih cepat dari waktu yang disediakan yaitu 10 minggu. Rata-rata frekuensi akses adalah 20,3 kali, dengan rata-rata waktu akses program untuk keseluruhan partisipan untuk setiap kali akses program adalah 35 menit, dengan rentangan waktu akses terlama adalah 79 menit, dan waktu akses tercepat 15 menit.

Hasil pengisian angket menunjukkan bahwa 12 dari 15 partisipan (80\%) menyatakan mampu memahami tahapan setiap modul dengan baik, 3 diantaranya (20\%) mampu memahami dengan cukup baik. Sebanyak 11 partisipan (73,3\%) mampu melaksanakan teknik-teknik yang diinstruksikan dalam modul dengan baik, 3 diantaranya (20\%) menyatakan mampu melaksanakan dengan sedikit kesulitan, dan $1(6,6 \%)$ mengalami kesulitan untuk menerapkan sebagian besar teknik. Dari segi tampilan, 13 dari 15 (86,6\%) responden menyatakan tampilan sudah menarik dan dapat fitur-fitur yang ada dalam sistem web psiko-edukasi dapat digunakan dengan baik, sementara 2 lainnya $(13,3 \%)$ menyatakan beberapa fitur membingkungkan. Dari aspek kebermanfaatan, 10 dari $15(66,6 \%)$ responden menyatakan program telah bermafaat terhadap diperolehnya pemikiran, sikap dan tindakan atau perilaku baru yang lebih baik untuk dirinya, sementara 5 lainnya atau $(33,3 \%)$ menyatakan cukup terbantu dalam memperoleh pemikiran dan sikap baru setelah mengikuti program. Hasil wawancara terhadap dua orang partisipan yang menyatakan mampu memperoleh pemikiran, sikap dan perilaku baru setelah mengikuti program menunjukkan bahwa mereka telah benarbenar mengimplementasikan teknik-teknik yang dipelajari dalam program psiko-edukasi berbasis web ini dalam kehidupan mereka sehari-hari, mereka merasa telah lebih mampu meningkatkan kemampuan untuk mengatasi permasalahan mereka dibandingkan sebelum mengikuti program ini. Sementara dua partisipan yang menyatakan cukup terbantu dalam memperoleh pemikiran dan sikap baru menunjukkan bahwa teknikteknik yang mereka pelajari dalam program belum sepenuhnya dapat diimplementasi dalam situasi kehidupan nyata mereka.

\section{Pengaruh Web Psiko-edukasi terhadap Gaya Hidup Kesehatan dan Resiliensi}

Tabel 1 menunjukkan bahwa nilai W pada data variabel resiliensi dan gaya hidup kesehatan (PPHLP) tidak signifikan $(>0,05)$ yang berarti sebaran data pada kedua variabel tersebut adalah normal. Sehingga pengujian menggunakan t-test dapat dilanjutkan (Goss-Sampson, 2019).

Tabel 1 Hasil Uji Noramlitas (Shapiro-Wilk)

\begin{tabular}{clrr}
\hline & W & $\mathrm{p}$ \\
\hline Resilieni sebelum & - Resiliensi setelah & 0.92 & 0.20 \\
PPHLP sebelum & - PPHLP setelah & 0.92 & 0.18 \\
\hline
\end{tabular}

Note. Significant results suggest a deviation from normality.

Pada tabel 1 dapat dilihat tentang skor rata-rata (M) dan standar deviasi (SD) skor resiliensi dan skor gaya hidup kesehatan partisipan sebelum dan sesudah mengikuti program psiko-edukasi berbasis web. Pada gambar 2 dapat dilihat perubahan skor yang terjadi antara sebelum dan setelah program diikuti oleh peserta pada pengukuran resiliensi (gambar 2a) dan PPHLP (gambar 2b).

Tabel 2 Rangkuman Hasil t-tes Kelompok Sampel Berpasangan (Paired sample t-test)

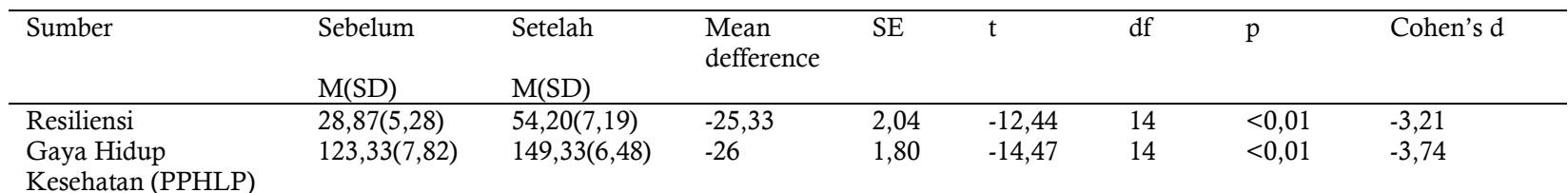

Note. For the Student t-test, effect size is given by Cohen's $d$. 
Note. For all tests, the alternative hypothesis specifies that the population mean is different from 15.

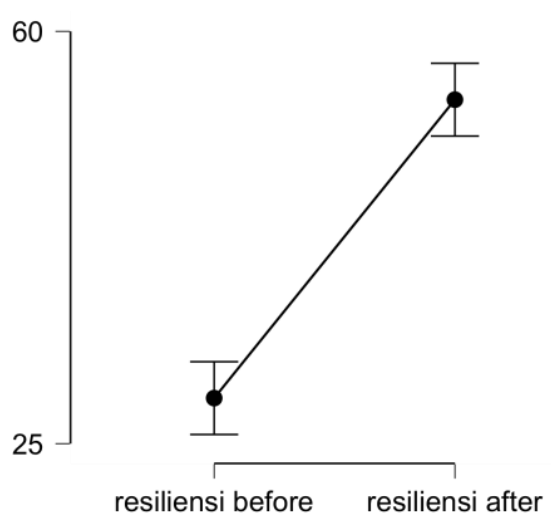

(2a. Resiliensi Sebelum dan Setelah Program)

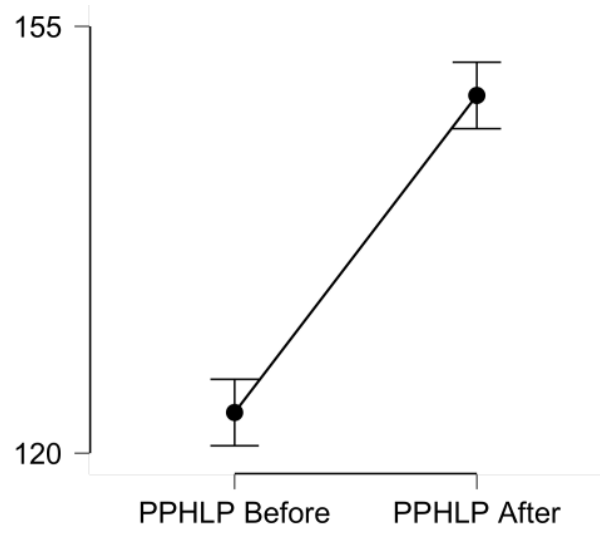

(2b. PPHLP Sebelum dan Setelah Program)

Gambar 2. Plot Deskripsi Resiliensi dan Gaya Hidup Kesehatan (PPHLP) Sebelum dan Setelah Mengikuti Program

Pada tabel 2 disajikan rangkuman hasil uji t sampel berpasangan pada amatan resiliensi dan gaya hidup. Hasil analisis menunjukkan bahwa setelah mengikuti program psiko-edukasi berbasis web selama rata-rata 9,5 minggu, partisipan mencapai peningkatan resiliensi rata-rata sebesar 25,33 (SE: 2,04) yang signifikan $(t(14)=-12,44, p<0,01)$. Nilai $d$ dari Cohen sebesar $-3,21$ yang menunjukkan bahwa adanya dampak pengaruh yang besar. Tanda minus (-) adalah menunjukkan arah perbedaan. Pada gaya hidup dan kesehatan (PPHLP), peningkatan rata-rata sebesar 26 (SE: 1,80) yang signifikan $(t(14)=-14,47, p<0,01$. Nilai $d$ dari Cohen sebesar -3,47 menunjukkan ukuran pengaruh yang besar.

Metode psiko-edukasi berbasis web ini merupakan metode baru dalam pendidikan, secara khusus dalam bimbingan konseling di perguruan tinggi. Sebelum diimplementasi secara luas, perlu dievaluasi keefektifan dan kebermanfaatannya sehingga diketahui apakah metode ini benar-benar relavan digunakan. Program psiko-edukasi berbasis website ini merupakan intervensi psikologis yang menggunakan metode daring (online) berbasis website yang bertujuan untuk melatih mahasiswa secara mandiri mengembangkan kemampuan-kemampuan yang dibutuhkan untuk mengatasi problematika psikologis, tekanan (stress), depresi, serta gangguan emosional dan perilaku lainnya dalam rangka mencapai kesejahteraan psikologis (Well-being).

Secara kuantitatif, hasil uji statistik telah menunjukkan bahwa psiko-edukasi berbasis website ini terbutkti efektif meningkatkan gaya hidup kesehatan dan resiliensi mahasiswa. Psiko-edukasi berbasis web ini menggunakan pendekatan konseling kognitif behavioral berbasis kekuatan (Suranata et al., 2017a). Sebagai model intervensi yang mapan, konseling kognitif behavioral telah memiliki bukti-bukti yang kuat melalui hasil-hasil studi emperik yang banyak menunjukkan efikasinya dalam membantu siswa mengatasi berbagai masalah atau kesulitan terkait dengan kecemasan, depresi, gangguan panik, fobia, tekanan psikologis atau stress, susah tidur, dan berbagai jenis gangguan emosi lainnya (Shea, 2016; Spirito, Esposito-Smythers, Wolff, \& Uhl, 2011; Yang et al., 2017). Model konseling kognitif behavioral yang selama ini lebih banyak diimplementasikan di sekolah adalah model konvensional yang berbasis pada masalah (deficit based intervence). Pada psiko-edukasi berbasis web ini adalah berbeda dengan itu. Psiko-edukasi berbasis web ini menggunakan konseling kognitif positif atau yang berbasis kekuatan (Bannink, 2014) yang lebih berorientasi pada pengembangan atau developmental. Program ini difokuskan pada upaya memberikan bantuan kepada mahasiswa dalam upaya mengembangkan sumber-sumber potensi dirinya untuk menghadapi masalah dibandingkan dengan upaya meyembuhkan atau membantu mereka yang telah mengalami masalah.

Selain menggunakan pendekatan konseling yang mapan, yaitu CBT, dan juga telah mengadaptasi paradigma baru, yaitu konseling yang berbasis kekuatan, metode psiko-edukasi ini menggunakan sentuhan teknologi yaitu metode daring (online) melalui media website yang saat ini telah menjadi bagian kehidupan remaja dan mahasiswa. Psiko-edukasi berbasis web ini dirancang dengan sistem yang dinamis, modul dirancang sesuai dengan kebutuhan subjek (mahasiswa) berdasarkan hasil asessmen pada tahap awal. Dengan bantuan media daring, website sistem psiko-edukasi ini dapat diakses oleh peserta kapanpun selama 24 jam, dan dimanapun, dengan perangkat computer yang terhubung jaringan internet ataupun dengan smartphone. Frekuensi akses mahasiswa peserta kegiatan ini cukup tinggi, dengan rata-rata akses, 20,3 x 35 
menit selama durasi 10 minggu. Frekuensi akses ini menunjukkan bahwa pada dasarnya sistem online psikoedukasi ini telah bekerja dengan baik. Hal ini juga didukung dengan hasil evaluasi dari mahasiswa yang mengikuti kegiatan ini yang memberikan respon sangat baik terhadap sistem. Semua aspek evaluasi yang digunakan yaitu dari aspek kemudahan dipahami, kemudahan diterapkan, kemenarikan serta kebermanfaatan rata-rata memperoleh penilaian yang baik dari sebagian besar mahasiswa peserta kegiatan. Namun demikian, meskipun jumlahnya sangat kecil, respon mahasiswa yang menyatakan fitur masih membingungkan dan sulit dimengerti tetap harus direspon dan dicermasti untuk pengembangan dan penyempurnaan program psiko-edukasi berbasis web ini.

Penelitian ini memiliki keterbatasan yang harus dipertimbangkan untuk dapat menginterprestasi hasil secara lebih cermat. Karena ini adalah pilot studi yang bertujuan untuk menguji kelayakan program psikoedukasi berbasis web dengan mode daring di lingkungan perguruan tinggi di Indonesia, jumlah mahasiswa yang direkrut untuk studi ini kecil yang berasal dari satu universitas. Untuk memastikan bahwa temuantemuan dari studi ini dapat digeneralisasikan, penting untuk mengevaluasi program dalam jangkauan subjek yang lebih luas dan melibatkan universitas yang lebih luas dari berbagai wilayah di Indonesia. Studi ini menguji program secera keseluruhan, yang didalamnya terdapat beberapa teknik-teknik dan modul yang bervariasi. Studi akan mendapat manfaat yang lebih baik apabila pengujian diakukan secara terpisah mengevaluasi setiap teknik dan modul dibandingkan dengan mengevaluasi program secara keseluruhan.

\section{Referensi}

Aaron B. Rochlen, S. N. B., \& Zack, J. S. (2004). The Online and Face to Face Counseling Attitudes Scales: A Validation STudy. Measurement and Evaluation in Counseling and Development, 37(July), 95-111.

Andersson, G., Cuijpers, P., Carlbring, P., Riper, H., \& Hedman, E. (2014). Guided Internet-based vs. face-to-face cognitive behavior therapy for psychiatric and somatic disorders: a systematic review and meta-analysis. World Psychiatry, 13(3), 288-295.

Bannink, F. P. (2014). Positive CBT: From reducing distress to building success. Journal of Contemporary Psychotherapy, 44(1), 1-8. https://doi.org/10.1007/s10879-013-9239-7

Goss-Sampson, M. A. (2019). Statistical ANALYSIS IN JASP: A Guide For Students.

Lee, R. L., \& Loke, A. J. (2007). Health-promoting behaviors and psychosocial well-being of university students in Hong Kong. Public Health Nursing, 22(3), 209-220. Retrieved from http://proxy.queensu.ca/login?url=http://search.ebscohost.com/login.aspx?direct=true \&db=cin20\& $\mathrm{AN}=106511182 \&$ site $=$ ehost-live

Manicavasagar, V., Horswood, D., Burckhardt, R., Lum, A., Hadzi-Pavlovic, D., \& Parker, G. (2014). Feasibility and effectiveness of a web-based positive psychology program for youth mental health: Randomized controlled trial. Journal of Medical Internet Research. https://doi.org/10.2196/jmir.3176

Shea, D. (2016). Cognitive behavioral approaches for counselors. Cognitive Behavioral Approaches for Counselors.

Spirito, A., Esposito-Smythers, C., Wolff, J., \& Uhl, K. (2011). Cognitive-Behavioral Therapy for Adolescent Depression and Suicidality. Child and Adolescent Psychiatric Clinics of North America. https://doi.org/10.1016/j.chc.2011.01.012

Suranata, K. (2018). Datasets Pilots Study web-based resilience program. https://doi.org/none

Suranata, K. (2019). Reliabelitas Gaya Hidup dan Kesehatan, adaftasi dari HPLP II. OSF. https://doi.org/none

Suranata, K., Atmoko, A., \& Hidayah, N. (2017a). Enhancing Students' Resilience: Comparing The Effect of Cognitive-Behavior And Strengths-Based Counseling. https://doi.org/10.2991/icirad-17.2017.20

Suranata, K., Atmoko, A., \& Hidayah, N. (2017b). Validation of Psychological Resilience Youth Development Module and Implication for Guidance and Counseling, 7(1), 68-77.

Swank, J. M., \& Tyson, L. (2012). School Counseling Site Supervisor Training: a Web-Based Approach. Professional School Counseling. https://doi.org/10.5330/PSC.n.2012-16.40

VicHealth. (2015). Interventions to build resilience among young people A literature review. VicHealth. Melbourne: Victorian Health Promotion Foundation. https://doi.org/10.1.1.45.1447

Walker, S., Sechrist, K., \& Pender, N. (1995). Health Promotion Model - Instruments to Measure Health Promoting Lifestyle : Health-Promoting Lifestyle Profile [HPLP II] (Adult Version). Journal of Nursing Research, 22(7), 796-811.

Walker, J. V, \& Lampropoulos, G. K. (2014). A Comparison of Self-help ( Homework ) Activities for Mood Enhancement : Results From a Brief Randomized Controlled Trial. Journal of Psychotherapy Integration. https://doi.org/10.1037/a0036145 
Winston, R., \& Chicot, R. (2016). The importance of early bonding on the long-term mental health and resilience of children. London Journal of Primary Care. https://doi.org/10.1080/17571472.2015.1133012

Yang, L., Zhou, X., Zhou, C., Zhang, Y., Pu, J., Liu, L., ... Xie, P. (2017). Efficacy and Acceptability of Cognitive Behavioral Therapy for Depression in Children: A Systematic Review and Meta-analysis. Academic Pediatrics, 17(1), 9-16. https://doi.org/10.1016/j.acap.2016.08.002 